\title{
Anthós
}

$5-31-2020$

\section{The Velvet Glove: Virtuousness and Class in Balzac's Paris}

Nicholas C. Peters

Portland State University

Follow this and additional works at: https://pdxscholar.library.pdx.edu/anthos

Part of the French and Francophone Literature Commons Let us know how access to this document benefits you.

\section{Recommended Citation}

Peters, Nicholas C. (2020) "The Velvet Glove: Virtuousness and Class in Balzac's Paris," Anthós: Vol. 9: Iss. 1, Article 5.

https://doi.org/10.15760/anthos.2020.9.1.5

This open access Article is distributed under the terms of the Creative Commons Attribution-NonCommercialShareAlike 4.0 International License (CC BY-NC-SA 4.0). All documents in PDXScholar should meet accessibility standards. If we can make this document more accessible to you, contact our team. 


\section{The Velvet Glove: Virtuousness and Class in Balzac's Paris}

Nicholas C. Peters

Honoré de Balzac's novel Père Goriot, tells the story of a tragic father who's blind love for his daughters drives him to ruin, as well as that of a young aristocrat who comes to Paris with dreams of conquering high society and taking his rightful place within aristocracy. As the characters in the story move throughout the city, Balzac renders a panoramic description of life in mid-nineteenth century Paris. This essay will examine how Balzac's use of space in the novel allows him to create a portrait of Paris as he saw it. Close inspection of the salon scene on pages $52 \& 53$ between Eugène and the residents of the Hotel Restaud (see appendix), and the identification and explication of key taxonomic elements in this passage paired with secondary scholarship will exhibit Balzac's critiques of values held by the aristocracy as well as the middle class and how it represents his views on the change occurring in Paris during this time period of urban modernity. After building a descriptive taxonomy within an significant passage in the novel, textual explication will be used to show relations between taxonomy and evidence based analysis that examines how these elements lead to an understanding of Balzac's views on what constitutes virtue and class in 19th century Parisian society.

This scene takes place during Eugène's first visit to the Chaussée d'Antin at the home of Anastasie, a vapid Comtesse from humble origins. After meeting at a ball, Eugène de Rastignac, a young man from the Provinces hoping to make a name for himself in Paris, has set his sight on the Comtesse de Restaud as his means of ascension.

The interaction between Eugène, the Comtesse, her husband the Comte de Restaud and her lover Maxime, is rich with textual elements that can be used to establish a robust taxonomy. The paramount device found in this passage is the narrator's description and use of imagery. The physical description of the 
characters appearances demonstrates how the characters perceive one another, and what traits they take into account when forming opinions. Language and diction also play a vital role in understanding the significance of the passage. The words used to describe the characters and their actions hold specific connotations that reveal deeper meanings within the description and dialogue present in the scene. There is also the indirect historical allusion to the Chaussée d'Antin, which must be considered when curating any aspect of the passage in order to form a historico-contextually accurate understanding of the text.

The passage begins when Eugène first sees Maxime. As the narrator describes him, Maxime's appearance creates a stark contrast between the two young men. His "handsome, fair, well curled hair" emphasizes the messiness of Eugène's, and his boots, "elegant and clean" draw his attention to the mud on his own (Balzac, 52). The description of Maxime is purely physical, and the aspects remarked upon by the narrator are those which are artificial. Eugène does not comment on his physique, or his looks, but on the clothes he wears, and the styling of his hair. Standards of beauty are not based on natural endowments, but on those which can be bought.

Maxime brings out a hatred in Eugène, as he perceives him to be flaunting the trappings of everything he hopes to become. Maxime has wealth, he has Anastasie, and he has a place in the aristocracy. The narrator states that Maxime "felt the superiority which his fine clothes gave," but what is truly felt is Eugène's sense of inferiority in the presence of such ostentation (Balzac, 52). He does not feel less than until he sees Maxime, who appears as more than. From his appearance Maxime is attributed with intelligence, elegance, and superiority without speaking a word. He embodies all the values of the Chaussée d'Antin through the fit of his waist coat and the curl of his hair. The idea that he so perfectly belongs there emphasizes the fact that Eugène does not.

Balzac's use of physical description and imagery in order to indicate supposed ethereal qualities reveals what traits and characteristics were used to 
define a person's character in Parisian high society. In Balzac's Heaven and Hell, Michel Philip alludes to Balzac's description of Paris as "a pretty woman" when describing the vanity and values of the city (Philip, 78). This same phrase is used to describe Maxime, whose "frock-coat most elegantly fitted around the waist, which made him look like a pretty woman" (Balzac, 52). This descriptor used by Balzac to describe both the city and the man further proves Maxime's right to superiority over Eugène. Maxime not only belongs in Paris, he is Paris, and Eugène is only a boy from the provinces with no carriage, and dusty boots.

Diction and dialogue are also used to uncover deeper meanings within the passage. The narrator describes the scene using precise language with words that carry connotations of battle, rage and violence. The use of diction in this passage reveals hostile undertones within the interactions and dialogue between characters that opposes an otherwise dull scene of aristocrats exchanging pleasantries in a parlor. The act of violence is repeatedly alluded to as the narrator describes the seemingly innocuous actions of the characters. Eugène feels a "violent hatred" for Maxime at first sight, as his appearance and ability to suit the lifestyle of the Chaussée d'Antin puts Eugène "in a fury" (Balzac, 52). As the narrator describes Maxime's ability to induce men into a duel to kill them, he rakes the fire with an "angry violence" (Balzac, 52). This description of masculine brutality is sensed by Anastasie, who is "fluttering up and down... like a butterfly," reading the tension between the two men clouds her "lovely face" with distress (Balzac, 53). The battle continues as the three "confronted each other" in front of the fireplace, this language creates almost a second nonverbal dialogue between the characters, that does not align with the spoken.

This subtext illuminated by Balzac's use of diction reveals the malice and antagonism that lurks beneath the opulent and polite façade of the aristocracy. This idea is remarked upon later in the novel when Eugène describes the inner workings of high society as "the iron hand beneath the velvet glove - the personality, the egoism beneath the manner, the wood beneath the varnish" 
(Balzac, 108). This unspoken rancor is affirmed by the narrator when Anastasie looks at him "in such a way that well-bred people would at once start composing those phrases known as exit lines" (Balzac, 53). Here, the narrator remarks on Eugène's inability to understand the social cues of the upper class, separating him further from the aristocracy.

This antagonism between the two men grows when the Comte de Restaud enters. He casts a "worried glance" at Eugène, but greets Maxime with a "friendly expression" (Balzac, 53). The words describing the Comte's attitude towards them further accentuates the difference in belonging between Maxime and Eugène. He is surprised by the Comte's manner towards Maxime because he is having an affair with his wife. The narrator attributes this surprise to his rural upbringing, stating that a boy from the provinces could not understand the "pleasures" of a love triangle.

A shift in diction and tone appears when the Comtesse finally introduces Eugène, emphasizing his relation to his cousin, the Comtesse de Beausánt. The introduction is given by the Comtesse with "pride" in the fact that she has a "person of distinction" in her house. This language indicates that Eugène is distinguished by his name alone, his birth is his greatest achievement in life. This revelation prompts a swift change in the behavior of Maxime and the Comte. This is seen through the description of their actions, as they both drop their "coldly formal," and "arrogant manners" (Balzac, 53).

The words used to describe the effect of his name exhibit the weight that a title bears in the Hotel Restaud, the Chaussée d'Antin, and all of Paris. The introduction of his name is comparable to divine intervention, described as the "wave of a magic wand" as everyone in the room is "affected by the potent mention of a name," though uneasy, even Maxime must succumb to the "magical effect" of his heritage (Balzac, 53). Eugène is also changed by this introduction. He is restored by this "flash of light" which gives him "clear insight" into the "murky atmosphere of Parisian high society," and returns the 
wit he lost when he first entered the home. His name has given him clarity and purpose, it is the only tool he needs to navigate the tempestuous waters of the aristocracy.

Creating this taxonomy reveals certain patterns in the text that create possibilities of meaning. The patterns found in the description of characters in relation to their worth, as well as diction used to reveal characters' perceptions and feelings lead to themes of virtue, ambition, and intelligence of the upper class in nineteenth century Paris. The idea of superiority and intelligence is first addressed during the description of Maxime. He perceives Maxime as the ideal, his ultimate goal. His hatred and jealousy spring from the fact that Eugène is not yet there. Maxime is attributed with beauty, intelligence, and superiority based solely on his appearance. The basis of comparison is based solely on Maxime's clothes, hair, carriage, and his relationship to Anastasie. Without speaking a word, he communicates to Eugène that his presence is unwelcome, and unwarranted.

Eugène did not feel inferior before visiting the Chaussée d'Antin, but when he enters the neighborhood, he finds himself lacking in qualities he once believed himself to possess. He did not change when he crossed the threshold of the Hotel Restaud, Paris did. Philip states that the city is a "moral milieu'. Each neighborhood is a living being characterized by its peculiar traits as well as by its history and especially its mores" (Philip, 78). The Chaussée d'Antin is the domain of the "nouveau riche," where wealth is virtue and noble blood is more valuable than gold. In a place where intelligence is found in the cleanliness of one's boots, Eugène is sure to be stupid.

It is not until he is made known as an aristocrat by birth that he gains any respect, or even acknowledgement from the residents of the Chaussée d'Antin. Eugène is enlightened by the power of his name, and now sees what is considered virtuous in the realm of the aristocracy. He regains his wit and "intelligence," and is confident in his ability to exist in high society. This is his first lesson on navigating Paris, that to move through society is "not to simply 
change social position, but also habits and morality; it is more than an alteration, it is a metamorphosis" (Philip, 79). This metamorphosis occurs when he hears his name and witnesses its sway over the aristocracy.

So, what is the purpose of explicating the morals of the aristocracy? By painting a portrait of the upper class and its values with descriptions of its members and their perceptions, Balzac unveils his critique of Parisian high society. Eugène's character acts as a lens through which to observe the aristocracy during Balzac's time. His struggle to understand how to behave and be accepted in the Chaussée d'Antin reveals what its residents base their values upon. Wealth is equated with virtuousness, but no amount of money can make one an aristocrat by blood. Therefore, to pervert the true nature of the aristocracy is immoral, and the opulence of the nouveau riche is false virtue.

Through this scene Balzac illustrates a Paris in which wealth and self-interest are the foundations of virtue. Eugène's greed and determination to dominate this world seen through the violent diction used to describe his perception of Maxime is also critiqued by Balzac. He is a classic Balzacian hero, a young man who comes from the provinces to take Paris by storm. His goals are not deplorable, but his willingness to succumb to the warped morals of the aristocracy in order to achieve them is his tragic flaw. This is an allusion to Balzac's critique of middle-class ambition due to the post-revolutionary ideal of social mobility, or the ability to change your status through entrepreneurship or marriage. Although Eugène is an aristocrat by blood, his upbringing in the provinces and his lack of wealth draws him as a symbol of the middle class in post-revolutionary Paris. The fact that he is able to move from the country to the city and worm his way into the upper class while lacking the virtue and status of an aristocrat is representative of the current state of Parisian society. This passage illuminates Balzac's views on the cultural change occurring in Paris. He believes the aristocracy is being perverted by the ambition of the middle class. The pre-revolutionary days of an impermeable upper class based on birthright has 
gone, and now class can be bought or married. The result of this corruption is the vapid ostentation of the residents of the Chaussée d'Antin. The nouveau riche embody the immoral ideals and the idleness of the characters in this passage. Balzac creates this scene as a condemnation of the current state of the aristocracy, as well as the greed and ambition of the middle class which further corrupts the values and integrity of the ruling class.

This piece has selected a key passage in Père Goriot and identified textual elements in order to create a taxonomy which reveals patterns from which Balzac's meaning stem. This essay used textual explication to analyze the descriptions, and diction used in the chosen passage to explicate a larger meaning in the novel. The contextualization of the text to the Paris in which Balzac lived, and the construction of an evidentiary archive from both the primary and secondary texts, offers a new understanding of the text and how it relates to Balzac's critique of aristocratic virtues in Parisian high society during the nineteenth century. 


\section{References}

Balzac, Honoré de, and A. J. Krailsheimer. Père Goriot. Oxford University Press, 2009. Accessed March 2020.

Philip, Michel. Balzac's Heaven and Hell. Yale French Studies, No. 32, Paris in Literature (1964), pp. 77-81. https://doi.org/10.2307/2929432. Accessed March 2020.

\section{Appendix}

"Rastignac felt a wave of violent hatred for this young man. In the first place Maxime's handsome, fair, well-curled hair showed him how messy his own was. Then Maxime's boots were elegant and clean, while his own, despite all the care he had taken on his walk, bore a light coating of mud. Finally Maxime wore a frock-coat most elegantly fitted around the wait, which made him look like a pretty woman, while at half-past two in the afternoon Eugène was wearing a black evening coat. The intelligent son of Charente felt the superiority which fine clothes gave to this tall, slim, clear-eyed, fair-skinned dandy, one of those men who are quite capable of bringing about an orphan's ruin. Without waiting for Eugène's reply, Madame de Restaud steed off into the other room, the skirts of her gown flittering up and down so that she looked like a butterfly. Maxime followed her. In a fury Eugène followed Maxime and the comtesse. These three then confronted each other by the fireplace in the centre of the great drawingroom. The student was well aware that he was going to be a nuisance to the odious Maxime, but at the risk of displeasing Madame de rested he wanted to be a nuisance to the dandy. Suddenly, remembering that he had seen the young man at Madame de Beauséant's ball, he guessed that Maxime's relationship to Madame de Restaud, and with that boldness which can lead the young into the silliest errors ors the greatest success, he said to himself: 'That's my rival, I will defeat him.' Unwise as he was, he did not know that Comte Maxime de Trailles liked to provoke insults, fire first and kill his man. Eugène was a good shot, but he had not yet knocked down went dolls out of twenty-two in a shooting gallery. The young comte flung himself into an easy chair by the fireside, tool the tongs and raked the fire with such angry violence that Anastasie's lovely face suddenly clouded with distress. The young woman turned to Eugène, and looked at him coldly as if to ask: 'But why don't you leave?' In which a way that well-bred people would at once start composing those phrases known as exit lines.

Eugène put on his most agreeable look and said, 'Madame I was in a hurry to see you to ...

He stopped short. A door opened. The gentleman who had been driving the tilbury suddenly appeared, bare-headed, did not greet the comtesse, cast a worried glance at Eugène, and held out his hand to Maxime, saying 'Good day' with a friendly expression which peculiarly surprised Eugène. Young men from the provinces know nothing of the pleasures of a triangular relationship. 
'Monsieur de Restaud,' the comtesse said to the student, indicating her husband.

Eugène bowed low.

'Monsieur,' she went on, introducing Eugène to the Comte de Restaud, 'is Monsieur de Rastignac, and is related to Madame la Vicomtesse de Beauséant through the Marcillacs. I had the pleasure of meeting him at her last ball.'

'Related to Madame la Vicomtesse de Beauséant through the Marcillacs!' These words which the comtesse had stressed almost unduly, prompted by the sort of pride with which a hostess proves that only persons of distinction are to be found in her house, produced magical effect. The comte dropped his coldly formal manner and bowed to the student.

'Delighted, Monsieur, to make your acquaintance.'

Comte Maxime de Trailles himself glanced uneasily at Beauséant and suddenly dropped his arrogant manner. This wave of a magic wand, affected by the potent mention of a name, opened up all the closed compartments of our Southerner's brain and restored the ready with which he had earlier prepared. A flash of light suddenly gave hime clear insight into what had so far been for him the murky atmosphere of Parisian high society. The Maison Vauquer and Père Goriot were at that moment far from his thoughts." 